\title{
Erratum to: Hips With Protrusio Acetabuli Are at Increased Risk for Failure After Femoroacetabular Impingement Surgery: A 10-year Followup
}

Markus S. Hanke MD, Simon D. Steppacher MD, Corinne A. Zurmühle MD, Klaus A. Siebenrock MD, Moritz Tannast MD

Published online: 22 June 2016

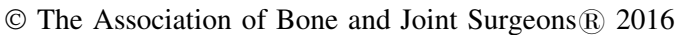

\section{Erratum to: Clin Orthop Relat Res \\ DOI 10.1007/s11999-016-4918-9}

Due to an error in production, the PDF version of this article was updated to correct the formatting of Table 6 .

Springer regrets the error.

The online version of the original article can be found under doi: 10 . 1007/s11999-016-4918-9.

M. S. Hanke ( $\bowtie)$, S. D. Steppacher, C. A. Zurmühle,

K. A. Siebenrock, M. Tannast

Department of Orthopedic Surgery, Inselspital, University of

Bern, Freiburgstrasse, 3010 Bern, Switzerland

e-mail: markus.hanke@insel.ch 